This is the author's Post-print version (final draft post-refereeing as accepted for publication by the journal). The definitive, peer-reviewed and edited version of this article is published as: Ubarevičienè R, Burneika D. \& van Ham M. (2015) Ethno-political effects of suburbanization in the Vilnius urban region. An analysis of voting behaviour. Journal of Baltic Studies.

http://dx.doi.org/10.1080/01629778.2015.1027935

\title{
Ethno-Political Effects of Suburbanization in the Vilnius Urban Region. An Analysis of Voting Behaviour
}

\section{Rūta Ubarevičienè, Donatas Burneika and Maarten van Ham}

\section{Rūta Ubarevičienè}

Department of Human Geography and Demography, Lithuanian Social Research Centre, Goštauto 11, LT-01108 Vilnius, Lithuania

OTB - Research for the Built Environment, Faculty of Architecture and the Built

Environment, Delft University of Technology, PO Box 5030, 2600 GA Delft, The Netherlands, ruta.ubareviciene@gmail.com,+37068797452

\section{Donatas Burneika}

Department of Human Geography and Demography, Lithuanian Social Research Centre, Goštauto 11, LT-01108 Vilnius, Lithuania, donatas.geo@gmail.com, +37068309821

\section{Corresponding author: Maarten van Ham}

OTB - Research for the Built Environment, Faculty of Architecture and the Built Environment, Delft University of Technology, PO Box 5043, 2600 GA Delft, The Netherlands, m.vanham@tudelft.nl, +31152782782 \& University of St Andrews, UK

\begin{abstract}
We use electoral data to analyze the ethno-political consequences that may arise from the fact that the region surrounding the city of Vilnius is dominated by residents with a Polish identity while those who move to the suburbs are mainly ethnic Lithuanians. In the suburban ring we found increasing voting turnout, a decreasing share of votes for the Polish party, and an increase of the absolute number of votes for this party. The changing electoral behavior might be an indicator of growing ethno-political tensions and the zones of the most intense changes identify areas of potential social tensions between ethnic groups.
\end{abstract}

Keywords: suburbanization; ethnicity; conflict; voting behavior; electoral data; Lithuania

\section{Introduction}

Political reforms in the early 1990s in the former socialist countries of Central and Eastern Europe led to major economic and social changes. These transformations have a clear expression in the spatial development of the major cities of post-communist Europe (Hamilton et al. 2005; Timar and Varadi 2001). Suppressed urbanization and rural retention during the Soviet period resulted in major changes in land use patterns after the introduction of the market economy in these states (Bertaud and Renaud 1997; Boren and Gentile 2007). One of the most significant features of this spatial process was urban expansion through the 
process of suburbanization (Nuissl and Rink 2005; Ouředníček 2007; Tammaru et al. 2009; Kok and Kovács 1999; Leetmaa and Tammaru 2007; Novak and Sýkora 2007). Like many other formerly centrally planned cities in Europe, also Vilnius - the capital of Lithuania - is undergoing rapid suburbanization, a process which started right after 1990 (see Ubarevičienè et al. 2011; Cirtautas 2013; Brade et al. 2009). The processes of urban sprawl and outward mobility in Vilnius are quite similar to what can be observed in other post-Soviet countries (Boren and Gentile 2007; Novak and Sýkora 2007; Krišjāne and Bērziņš 2009).

What makes the case of Vilnius specific is the ethnic landscape of the central city and the region surrounding the city. Due to historical reasons, the region surrounding Vilnius is dominated by ethnic minority groups (with a prevalence of Poles), and it is regarded as the most multinational region of Lithuania (Stanaitis and Česnavičius 2010). Ethnic minorities comprise $37 \%$ of the Vilnius city population and approximately $65 \%$ of its' recent suburbanization zone (Statistics Lithuania, 2012). In addition, the ratio of different national groups differs considerably between the central city and the region surrounding it. Although Poles comprise around half of the population in the zone of suburbanization, they form a clear majority in the areas that are still unaffected by suburbanization (more than $90 \%$ in some LAU 2 regions) and less than one fifth in the central city. What makes Vilnius unusual in an international context is that the spatial pattern of ethnic composition is the opposite of what can be found in many other European cities where the central city has a high share of ethnic minorities and where the commuter ring around the city is dominated by the titular ethnic group.

The recent process of suburbanization around Vilnius, which takes place in the territories predominated by ethnic minorities, might cause ethnic tensions. As has been observed in many other countries, (Tammaru et al. 2013; Bonvalet et al. 1995; Clark 2006; Simpson and Finney 2009; Hiebert 2000) the ethnic majority population is often overrepresented among those who suburbanize. This is not different in the case of Vilnius where Lithuanians suburbanize to the surrounding city region where Polish identity residents are traditionally the largest group. The outward expansion of Vilnius city results in a confrontation of ethnic groups in the suburbs, with partly different needs, priorities, worldviews, quality of life standards, and value systems (Burneika and Ubarevičienè 2011). Ethnic, social, economic, and political contrasts are evident between the old residents of the city region and the newcomers. That the encounter of the two groups can lead to potential conflicts is illustrated by increasing media attention on the growing political activity of the Polish minority in the Vilnius region and possible links with the ethnic dimensions of the ongoing suburbanization process.

The aim of this paper is to explore the ethno-political effects of suburbanization in the Vilnius region by studying voting behavior. As George and colleagues (2010) argue, a strong salience of group identity can be revealed through political action. The vast majority of ethnic minorities in the region surrounding Vilnius city support the Polish political party, which acts almost exclusively in their interest. We expect that the suburbanization process and voter migration might have consequences for electoral results in the surrounding city region. We hypothesize that the number of votes for the Polish party and voting turnout will increase in the suburban ring because of the mobilization of Poles, aiming to strengthen their political influence during a time when others enter the region. By analyzing changes in voting behavior we will also identify the zones where future ethno-political tensions are the most likely. This study uses electoral data of the 1997 and 2011 municipality elections. The Lithuanian Census of 1989, 2001, and 2011 provide us with information about population change and ethnic composition. The smallest possible statistical units - voting districts and seniūnija (LAU 2 or previous NUTS 5 level) are used to give precise territorial data. Cartographical analysis and 
statistical techniques are used to investigate the correlations between socio-spatial transformations and voting behavior in the Vilnius urban region. The cartographical approach has important added value because of the geographical nature of the topic under study. The approach is capable of identifying (changes in) spatial patterns of population distribution and voting behavior.

\section{Theoretical Background}

There are many different factors that influence the electoral behavior of people, and shifts in such behavior over time. The most relevant factors are differences in social structure, public opinion, economic and political conditions, and characteristics of the political parties involved (Lubbers et al. 2002). There is a substantial body of literature that investigates the causal relationship between ethnicity and voting behavior. Wolfinger (1965) argues that ethnicity plays a major role in politics, and it is often an important independent variable in voting behavior. The presence of ethnic voting has been confirmed by many studies (see, for example, Chernyha and Burg 2012; Crowley 2001; Medrano 1994; Walks 2006). It is common that ethnic minorities have different political preferences and support different political parties than the rest of the population. That is especially likely if there are political parties which appeal exclusively to a particular ethnic group. In this case, a political cleavage might emerge (see Lipset and Rokkan 1967 on cleavage formation). Lawson (1999) defines cleavages as "long-term structural conflicts that give rise to opposing political positions, which may or may not be represented by parties."

Numerous studies have also noted that ethnic minorities are less likely to vote than the majority population (Bullock and Hood 2006; van Heelsum 2005; Fennema and Tillie 2001; Crowley 2001; Togeby 1999). However, if political parties representing the interests of ethnic minorities join the elections, this might mobilize ethnic minority voters to express their political views more actively in order to gain greater socio-political influence (George el al. 2010; Wolfinger 1965; Chandra and Wilkinson 2008). According to Crowley (2001), political participation of ethnic minorities can also reflect their identity processes.

Electoral geography literature pays increasing attention to the effects of migration on electoral results (Robinson and Noriega 2010; Halla et al. 2012). In countries or regions with relatively high levels of (international) immigration, native residents who feel threatened often vote for right-wing political parties, which proclaim anti-immigrant attitudes in their programs, in an attempt to protect their labor market and safeguard their own cultural identity (Lubbers et al. 2002; Arzheimer 2009). Meanwhile, immigrants support liberal or ethnic parties representing their interests. Such political battles are going on in many western European countries. Voting results can also be influenced by more local level migration flows, for example, migration from the city to the suburbs. Walks $(2004,2005,2006)$ has shown that there is an increasing polarization in terms of political attitudes and party preferences between the inner cities and the suburbs in the United States, Canada, and Great Britain. The outward expansion of cities may lead to a shift in the balance of political power in its suburbs as new residents arrive with different political preferences. This may cause more active political involvement of the original residents of the region surrounding the city in order to keep their political dominance. Such a process can be expected to be more pronounced if there are ethnic differences between newcomers and the original population, such as is the case in the city region of Vilnius. Although the voting behavior of ethnic minorities in Lithuania had been analyzed by authors such as Ramonaite, Matulevičius and 
Degutis (2007) and Degutis (2002), no research has investigated the potential effects of suburbanization on electoral results.

In the next section we will discuss the socio-spatial transformations which took place in the Vilnius region during the last few decades, starting with a brief history of the region.

\section{Socio-Spatial Transformations in the Vilnius Urban Region}

\section{Ethnic composition of the Vilnius region}

Currently, more than $90 \%$ of Polish identity residents in Lithuania are concentrated on $8 \%$ of the land mass, which is the Vilnius region. The contemporary presence of Poles, the most numerous ethnic minority group in the Vilnius region, is strongly rooted in history. The Polish population reached its peak during the period of Polish governance in the Vilnius region between 1920-1939. This period showed a strong growth of the Polish population as well as a strengthening Polish identity of local residents throughout Vilnius region. Simultaneously, the rest of Lithuania was an independent state from 1918 to 1940, which strengthened the Lithuanian identity across this part of the country. Just before the Second World War, Lithuanians made up about $10 \%$ of the population in the Vilnius region and more than $80 \%$ in the rest of the country (Gaučas, 1997).

The Second World War marked the end of Polish governance and the beginning of the Soviet period. This shift in power was accompanied by Polish repatriation, especially from the city of Vilnius (Daukšas 2008; Stravinskienè 2004; Eberhardt 2006). At the same time, mass industrialization, which began soon after the start of the Soviet occupation, accelerated the growth of Vilnius city. The population of the city increased 3.4 times from 1950 to 1989 (Stanaitis and Česnavičius 2010; Stanaitis 2003; see also Enyedi 1996; Krišjāne and Bērziņš 2009; Sýkora and Ouředníček 2007 on industrialization in Soviet cities). Vilnius city received immigrants from other parts of Lithuania and from more remote areas of the Soviet Union. Hence, the ethnic differences between Vilnius city and the rest of the country reduced during the Soviet period. At the same time, the effects of the Second World War and the Soviet regime were relatively weak on the region surrounding Vilnius city, and the population of this region continued to consist primarily of Polish residents.

The ethnic structure of the Vilnius region underwent one more period of change in recent history: in the period since the restoration of Lithuanian independence in $1990^{1}$. Like in many other post-Soviet cities, part of the Russian-speaking residents emigrated from Vilnius (see Tammaru and Kulu 2003; Commercio 2004). As a result, the proportion of Lithuanian people in the city has grown significantly since 1989, rising by $12.7 \%$, and currently consisting of $63.2 \%$ of the city population (Statistics Lithuania, 2012). The period since independence has also brought changes in the region surrounding the city. The Polish population, which dominated here since the $20^{\text {th }}$ century, has started to shrink (by 14,500 in 2001-2011) and its relative share declined by 3.2\% throughout the surrounding Vilnius region. The ethnic landscape of 2001 and recent changes in this landscape are illustrated in Figure 1, which shows information from the 2001 and 2011 censuses (Statistics Lithuania, 2002; Statistics Lithuania, 2012). The map on the left shows the ethnic segregation in the

\footnotetext{
${ }^{1}$ During the political reforms around 1989-1990, the citizenship act was introduced in Lithuania. According to this act all permanent residents of the territory of Lithuania, regardless of their countries of origin, were able to acquire Lithuanian citizenship. This was accepted by $90 \%$ of the non-Lithuanian residents. Those who accepted the citizenship also gained voting rights in elections.
} 
Vilnius region, with Lithuanians who dominate the city and Polish residents who dominate the surrounding region. The map on the right shows the decline in the proportion of Poles, especially in the suburban ring around the city of Vilnius. Although, in general the population of Poles has decreased more than the population of ethnic Lithuanians, some areas to the outside of the Vilnius region have experienced a very small relative increase in the Polish population. Currently, ethnic minorities comprise approximately $56 \%$ of the population in the region surrounding Vilnius city, with the largest ethnic groups being Poles (43\%), Russians (7\%), and Byelorussians (3\%). Meanwhile, ethnic minorities form 37\% of the population in the city of Vilnius, with the same ethnic groups being the most numerous: Poles $(16.5 \%)$, Russians (12\%) and Byelorussians (3.5\%).

Figure 1. Ethnic landscape of the Vilnius region.

Source: Data provided by Statistics Lithuania.

\section{Urban sprawl}

Like in many other Central and Eastern European cities, during the Soviet times, the hinterland of Vilnius was devoted exclusively to agricultural and associated industrial production (see, for example, Leetmaa and Tammaru 2007; Sýkora and Ouředníček 2007; Tammaru et al. 2009). The absence of a real estate market and the absence of private property contributed to the situation that, until the 1990s, suburbs did not exist (Bertaud and Renaud 1997; Krišjāne and Bērzinšs 2009; Sýkora and Ćermák 1998). Compact high-density residential housing estates at the edges of cities, and large industrial areas within their limits, were among the most important features of urban development in the Soviet times, where spatial planning was carried out by the Communist Party (Vanagas et al. 2002). During the Soviet era, there was an active policy to reduce the dominance of large cities by the development of new regional centers and promoting decentralization of industry (Šešelgis 1996; Tammaru 2009; Enyedi 1996). In Lithuania this meant that part of the potential growth of Vilnius was distributed to other regions of Lithuania. Although, the administrative territory of Vilnius city has gradually expanded, penetrating into the areas dominated by Poles, this process was slowed due to the restrictions of Soviet planning policy.

Figure 2. Urban sprawl of Vilnius.

Source: Data provided by Statistics Lithuania.

After the collapse of the Soviet Union, the introduction of a free market economy, and privatization liberated the previously constrained Vilnius growth potential and allowed the city to expand very quickly (Figure 2; Ubarevičienè et al. 2011; Cirtautas 2013). This led to uncontrolled urban sprawl of vast low density single-family residential areas into the rural region surrounding Vilnius, an area dominated by Polish identity residents (compare Figures 1 and 2). The administrative territory of Vilnius city municipality has grown by $30 \%$ between 1990 and 2001, and since the restoration of Lithuanian independence in 1990, the population in the suburban zone has increased by approximately $30,000(+20 \%)$, while in the city population has decreased by $40,000(-7 \%)^{2}$. As a result of these changes, a functionally and spatially integrated urban system developed in the region (Harrison 2010; Sýkora and

\footnotetext{
${ }^{2}$ Population decline is the prevailing trend in Lithuania. The country lost $17.2 \%$ of its population between 1989 and 2011. The population dropped in most areas, including the main cities and increased only in the regions surrounding these cities, including the suburbanization zone around the city of Vilnius.
} 
Ourredníček 2007). It is worth mentioning that the city of Vilnius, which is regarded to be the economic motor of Lithuania, is expanding into one of the economically least developed areas. The suburban zone is now a site of increasing interaction between the original residents, many of whom have a Polish identity, and newcomers who are mainly of Lithuanian origin.

\section{Mobilization of the Polish vote and the potential for conflict}

The Polish political party, Electoral Action of Poles in Lithuania (EAPL), has a significant impact on Polish minority identity-building. The party was established in 1994, and had the aim of unifying the Polish identity residents in the Vilnius region, and to defend their interests. Since then the electorate of the EAPL has grown steadily. The campaigns of the party emphasize issues of particular interest to ethnic minorities, and especially to Polish identity residents, but the party also serves as a party of regional defense (Andžejevski 2014). Some argue in the media that the problems raised by the EAPL are exaggerated and their promotion is only needed in order to mobilize its voters and to maintain the political influence of the party in the Vilnius region (delfi.lt, 2014). Petrulis (2009) even went so far as to argue that the Vilnius region has now become an independent social-political entity in Lithuania. More than $70 \%$ of votes in the municipal elections went to the EAPL in the region surrounding Vilnius city. In some areas, populated mainly by the Polish identity residents, EAPL gained up to $95 \%$ of votes in the municipal elections and up to $80 \%$ in the national elections during the recent decade (Central Electoral Commission, 2012). Since its foundation, the EAPL had a majority position in the councils of municipalities in the region surrounding Vilnius city. There is little political competition in the region as there is little to gain for other political parties due to the large Polish presence in the region. In Vilnius city, where the share of ethnic minorities is much smaller, the position of the EAPL is less strong and a broader spectrum of parties is elected. However, it should be noted that support for the EAPL is growing in Vilnius city as well, which is most likely the result of a mobilization of the Polish vote.

Because of the process of suburbanization, the share of Lithuanians is increasing in the region surrounding the city of Vilnius, and this might lead to a shift in the balance of political power in the suburban ring of the city. It can be expected that both Polish identity residents and Lithuanians feel the urge to be represented politically. Mobilizing voters can be expected to be especially important for the EAPL, because this political party holds a majority in the region and needs to defend its local political dominance. On the other hand, there is no direct single threat for the EAPL as ethnic Lithuanians vote for a broad set of other political parties without having a clear favorite. Moreover, those who recently suburbanized to the region may be less likely to vote as these new suburban residents often have stronger social relations with the city of Vilnius and are less concerned about the local politics of the suburbs.

Although people in the Vilnius region are used to living in a multicultural region, and people of the different ethnic groups are comfortable living side by side without any serious conflicts, the recent process of rapid urban sprawl, and thus increasing interactions between Poles and Lithuanians, may cause tensions. The suburban ring of Vilnius might therefore become a possible stage of social and ethnic tensions between Polish residents and the incoming Lithuanians. In 2010, we conducted fieldwork in the rural areas surrounding the city and visited offices of the local governments and interviewed their staff. We found that there are tensions between the original population (the majority of whom are Poles) and the incoming population (the majority of whom are Lithuanians), but none of the respondents emphasized that ethnicity was at the roots of these tensions. The issues mentioned that caused tensions were related to the different needs, different priorities, and a gap in quality of life 
standards between the old residents of the region and the newcomers. Often tensions originated from newcomers demanding better transport infrastructure, improvements in watersupply systems, or waste collection, whereas the original residents were against most changes with an impact on their immediate environment. The interviews suggested that differences in economic situation were more relevant than ethnic differences.

Ethnicity may, however, be an important underlying factor in determining a range of social tensions in the region, which may be reflected in voting behavior. The national media suggests that there are tensions related to the ethnic dimension in the Polish dominance of the region. Although the subject of these tensions is not directly linked to the process of suburbanization and concerns the Polish minority as a whole, it is likely that the suburbanization process is part of the stimulus. One of the hot topics is the educational system (15min.lt, 2012; Audenienè, 2013; Miškinytė 2011; Alkas.lt, 2012; Respublika, 2011; Media, 2013). The provision of education in Lithuania is the responsibility of local municipalities. This means that in municipalities where Polish identity people have a majority in local government, they can keep Polish schools open, even when the Polish population is shrinking and the number of Polish pupils decreases even faster. There is a national policy to reduce the number of schools with few pupils, but in the areas dominated by Polish identity residents these schools are kept open. At the same time there is no increase in the number of Lithuanian-language schools in areas of intense suburbanization and increasing numbers of Lithuanian pupils (Statistics Lithuania, 2011). Any interference of the national government in this matter is labelled as discrimination of ethnic minorities. Moreover, the media regularly reports on other issues of importance to the EAPL and its supporters. For example, over the past several years the EAPL has asked the Lithuanian government for permission to use the Polish alphabet for writing names in passports of Polish identity residents, and to put up bilingual street and village names in municipalities where Poles dominate (Press Europe 2009; 15min.lt 2013; The Economist 2012; The Lithuania Tribune 2013). Such actions by the EAPL are not only in the interest of their supporters, but also in the interest of the party as they work as an effective tool to mobilize voters who help to keep the dominant positions of the party.

\section{Hypotheses}

We expect that the suburbanization process and voter migration might have consequences for electoral results in the region surrounding the city of Vilnius. First, we expect to find a negative relationship between population change and the share of votes for the Polish party (hypothesis 1). We expect that in those areas where there is an increase in population (suburban zone), there will be a decrease in a share of votes for the Polish party. We also expect that the inflow of ethnic Lithuanians in the region surrounding the city of Vilnius will lead to a mobilization of the vote of the original Polish population. Based on our literature study, we expect that the Polish identity voters in the suburban ring will more often vote for the Polish party, and will show an increase in voting turnout in order to strengthen their political influence in a time when others enter the region. However, because we use aggregate level data, and not individual level data, we cannot directly test hypotheses on the individual level. We therefore formulated a hypothesis on the aggregate level of voting districts. We expect to find that there is an increased ratio between the Polish population and the absolute number of votes for the EAPL in the Vilnius region, especially in the zone of suburbanization (hypothesis 2). As supporting evidence of the changing voting behavior, we expect the absolute number of votes for the EAPL to go up, and we expect that there is an increase in voting turnout in the region. In the conclusion of the article we discuss how our aggregate level results might be explained by underlying mechanisms at the individual level. 


\section{Data and Methods}

To test our hypotheses, we used the voting results of the 1997 and 2011 municipality elections. We analyzed municipal elections instead of the national elections, because they represent the residents' concern of having their representatives in local governments. Since we are interested in the electoral behavior of ethnic minorities, we only analyzed votes on the Polish political party (EAPL) and voter turnout. Our study uses aggregated data for voting districts, which is the lowest spatial level available in Lithuania for elections' results. Electoral data are not available on the individual level, and therefore cannot be combined with individual characteristics (e.g., ethnicity, household structure, etc.). Since the aim of this study is to explore the relationship between suburbanization and the changing electoral behavior of the Polish minorities, we needed detailed data on the ethnic composition of the population on a low spatial level, which is not available for voting districts. We therefore had to aggregate voting data on the level of seniünija, which are somewhat larger than voting districts (193 voting districts formed 68 seniūnija). Because the two different territorial levels do not coincide completely, some bias might result from the aggregation process.

According to the Lithuanian law, each of the voting districts cannot contain more than 5,000 voters, and officially there are no marked boundaries of these units ${ }^{3}$. Moreover, the number of voting districts, as well as their size, has changed over the research period, which makes comparison over time a challenge. We have mapped the limits of voting districts to get a clear representation of their territorial dimensions. These boundaries were approximated and homogenized into a unified grid, which was used to compare data of election results in different years. We took the most recent voting districts as a basis and mapped the voting results of previous years onto this grid. We used cartographical tools to present the spatial pattern of voting results and the changes over time. The combination of cartographical methods and statistical techniques gives good insight into voting patterns.

Since the process of urban sprawl is central to this study, in the empirical part of the paper we are limiting our exploration of voting data to the region, which is under the direct influence of Vilnius city. This research area, including the city of Vilnius, covers about 8,000 $\mathrm{km}^{2}$ with approximately 750,000 inhabitants in total, and 316 voting districts. The region surrounding the city of Vilnius covers $7,600 \mathrm{~km}^{2}$ with 220,000 inhabitants in total, and 193 voting districts. In this region, a voting district contains approximately 1000 voters and covers $44 \mathrm{~km}^{2}$. In the empirical part of the paper we will analyze data for three different territorial units: the region surrounding Vilnius city, which is split into the zone of suburbanization, and Vilnius region beyond the suburban zone.

\section{Results}

\section{Ethnicity and voting behavior}

There have not been any detailed studies in Lithuania investigating the relationship between ethnicity and political preferences expressed through voting behavior. Post-election opinion surveys conducted in Lithuania in the period 2006-2009 showed that mainly Poles, and to some extent other ethnic minorities, vote for the EAPL (Lithuanian HSM data archive, 20042010). In addition, the very large and significant correlation between the share of Polish identity residents and the share of votes for the EAPL in municipal elections suggests that a decisive factor in determining voting preferences for a large proportion of the population is their Polish identity (1997, $\mathrm{r}=.923, \mathrm{n}=89, \mathrm{p}<.0005$ and 2011, $\mathrm{r}=.928, \mathrm{n}=89, \mathrm{p}<$

3 Each district serves its own addresses, streets, individual neighborhoods, houses or villages. 
$.0005)$. Based on these results, we argue that it is reasonable to assume that it is mainly Polish identity people who vote for the EAPL, even though individual level data is not available.

The scatterplots in Figure 3 show that the higher the share of the Polish population in an area, the higher the share of votes received by the Polish party. The R-square coefficients show that each model explains approximately $86 \%$ of the variance in the data.

Figure 3. Share of the Polish Population and Share of Votes for the EAPL on the Level of Seniūnija.

Source: Data provided by Statistics Lithuania and the Central Electoral Commission of the Republic of Lithuania.

Figure 4 shows the differences in voting results between Vilnius city and the surrounding region in both the 1997 and 2011 municipal elections. The region surrounding the city is characterized by large support for the Polish political party, with the EAPL yielding as much as $95 \%$ of the votes in a large number of voting districts. The city of Vilnius itself is characterized by much lower levels of votes for the EAPL with less than $15 \%$ of the votes going to this party for most of the city.

Figure 4. Relative Share of Votes for the EAPL in Voting Districts in the 1997 and 2011 Municipality Elections.

Source: Data provided by the Central Electoral Commission of the Republic of Lithuania.

Although, we have argued above that the party's popularity was steadily growing since 1994, the relative support for the EAPL decreased in many areas of the Vilnius region. Figure 5 shows the spatial changes in the proportion of voters supporting the EAPL between 1997 and 2011. The map shows an overall picture of decline in the relative support for the EAPL, except on the edges of the Vilnius urban region and in some parts of the city of Vilnius itself. These changes can be caused by changes in the population composition of areas, or by changing voting behavior of residents. It can be seen that almost the whole zone of suburbanization shows a decline in the relative support for the EAPL.

In order to better understand the observations from the maps, we looked at the correlations between the relative change in the population and relative change in the votes for the Polish political party over the period of 1997-2011. We wanted to get more insight in the relationship between population change and voting behavior. We found that the correlation between population change and relative change in the votes for the EAPL was negative in both the suburban zone $(\mathrm{r}=-.595, \mathrm{n}=17, \mathrm{p}=.012)$ and in the rest of the region (excluding the zone of suburbanization and the city of Vilnius) $(\mathrm{r}=-.330, \mathrm{n}=55, \mathrm{p}=.014)$. Although the correlation was significant in both zones, it was considerably stronger in the suburban zone, which means that the most significant changes in local electoral behavior can be observed in those regions where intense suburbanization took place. These findings confirmed our first hypothesis.

The negative correlation in the suburban zone might be explained by the increasing share of ethnic Lithuanians (see Figure 1). Meanwhile, the negative correlation in the wider region is likely to be associated with spatial variations in terms of voting results in combination with negative population change and a changing ethnic composition. An increase in the relative support for the EAPL in some voting districts to the outside edge of the Vilnius region is likely to be an artifact of small numbers of votes for the EAPL in 1997 and 2011, so even small changes in the number of votes can cause changes in the percentages. Although we 
expected that the share of votes for the EAPL would decrease less considerably in the areas outside the suburban zone, the opposite can be observed in some voting districts. Apparently, the voting results depend on the EAPL's ability to motivate its voters both nationwide and on the local scale. Therefore, it might differently affect the voting behavior in different locations. The effect of suburbanization may also differ in different local political contexts.

Figure 5. Changing share of votes for the EAPL in voting districts in the 1997-2011 municipality elections.

Source: Data provided by the Central Electoral Commission of the Republic of Lithuania.

The decrease in the relative support for the Polish party in the zone of suburbanization is most likely related to the flow of population from the central city to the surrounding Vilnius region. Newcomers in the suburban zone, most of whom are ethnic Lithuanians, have different political preferences than the original population. The increase of Lithuanians in the region dominated by Polish identity residents redistributed the rankings of the competing political parties. Migration flows can have major effects on electoral change even in places without large groups of ethnic minorities (see Robinson and Noriega 2010 on the theory of voter migration; and see Halla et al., 2012 on causal effects of immigration on election outcomes).

The maps show that there is an increase in the relative support for the EAPL in some zones which are not affected by urban sprawl, namely the central and most peripheral parts of the region. The increase of the share of votes for the EAPL in the city of Vilnius could be explained by the outflow of voters for other parties, but there are no data confirming this hypothesis. It is also possible that the Polish population in the city became more politically active. However, one of the important factors for this increase of support for the EAPL in the city was that just before the 2011 elections, the EAPL formed an electoral coalition with the Russian ethnic party, Russian Alliance (RA), in the municipalities of the Vilnius region. Within this coalition ${ }^{4}$ the EAPL was a dominant force. Although the RA has never been popular in the region surrounding Vilnius, and did not participate in recent municipal elections in the region (except in one unsuccessful case in one of the municipalities), it had a more significant role in Vilnius city (the RA received 4.4\% of votes in the 2007 Vilnius city municipal elections). The collaboration between the EAPL and the RA enabled the EAPL to strengthen its position in the central city, although support for the coalition with RA remained relatively low in the city compared with support in the rest of the region. The substantial increase of the share of votes for the EAPL in the more remote parts of the larger region cannot be explained only by the formation of the coalition, because of the small proportion of the Russian population in these areas. This increase is most likely the result of the enhanced voter's mobilization efforts of the EAPL in the region. Contrary to the suburban zone, these efforts were more influential in the peripheral part of the region, where Polish residents comprise the majority of the population, and where the changes in population (its number and ethnicity) are negligible. It must be noted that despite the general trend of decreasing share of votes for the Polish political party, it still receives more than $50 \%$ of the votes in most of the voting districts in the region surrounding the city of Vilnius, especially in its periphery.

\section{Increasing absolute number of votes for the EAPL}

\footnotetext{
${ }^{4} \mathrm{We}$ will use the term EAPL in the remaining parts of the paper when talking about the coalition of the EAPL and RA in 2011.
} 
Although the relative share of votes for the EAPL has dropped by $4.1 \%$ between 1997 and 2011 in the surrounding Vilnius region (see Figure 5), Figure 6 shows that the absolute number of votes for this party actually increased by $12,000(33.5 \%)$ during the same time. In the zone of suburbanization there was an increase of 7,500 (55\%) votes for the EAPL, and a $4 \%$ decrease in share of votes for this party. These results are striking as the Polish population decreased in absolute numbers during the same period.

Because we use aggregate data, we cannot draw conclusions on individual level voting behavior. However, post-election opinion surveys (Lithuanian HSM data archive, 2004-2010) show that it is mainly Polish identity people who vote for the EAPL, which therefore suggests that Polish voters became more active in the Vilnius region, especially in the suburban zone. Further support for this hypothesis are the correlations (see Table 1) between the absolute number of Poles and the absolute number of votes for the Polish party, which became stronger in the region as a whole in 2011 compared to the results of 1997. It should be noted that the increase in the correlation was substantial in the zone of suburbanization. The strongest correlation between the two variables was found in the region beyond the suburban zone, which suggests that Poles are most likely to vote for the Polish party in this area. However, the differences were very small throughout the region, especially in 2011.

Figure 6. Change in the Absolute Number of Votes for the EAPL in Voting Districts in the 1997-2011 Municipality Elections.

Source: Data provided by the Central Electoral Commission of the Republic of Lithuania.

Table 1. The Correlations between the Absolute Number of Poles and Absolute Number of Votes for the Polish Party in the 1997 and 2011 Municipal Elections on the Level of Seniūnija.

Source: Data provided by Statistics Lithuania and the Central Electoral Commission of the Republic of Lithuania.

To get more insight in our data we also calculated the potential ${ }^{5}$ ratios of voting turnout amongst different population groups, and for different areas (Table 2). The ratios have been calculated for three groups: the whole population, the Polish population, and the non-Polish population. We used data on total voting turnout, the number of votes for the EAPL, and the number of votes for other parties. We included the whole population in our calculations, not only those with voting rights, and as a result, the percentages of voting turnout is relatively low. According to the Central Electoral Commission the general turnout level in 2011 elections was higher than that in 1997 in the whole country $(35.6 \%$ in 1997 and $44.1 \%$ in 2011). Table 2 suggests that the voting turnout increased among all groups and in all specified areas, but that the increase was higher in the Vilnius region compared to Lithuania as a whole. What is of special interest here is that Poles stood out by the highest increase in potential voting turnout in the zone of suburbanization. This increase was equal to $17.9 \%$ while the increase among the whole population was $11.8 \%$ in this zone, compared to the general increase of $9 \%$ in the country. This finding confirmed our second hypothesis.

\footnotetext{
${ }_{5}^{5}$ Polish people do not necessarily vote for the Polish party, but as shown above, the significant and very strong correlation between the share of the Polish population and share of the votes for the EAPL, and post-election opinion surveys, suggest that a decisive factor in determining voting preferences of a large proportion of the population is their Polish identity and the mobilization of votes.
} 
Table 2. The Ratios of Voting Turnout amongst Different Population Groups in the 1997 and 2011 Municipality Elections on the Level of Seniūnija.

Source: Data provided by Statistics Lithuania and the Central Electoral Commission of the Republic of Lithuania.

Comparing the 2001 and 2011 Censuses (Statistics Lithuania 2002; Statistics Lithuania 2012) shows that the total population in the zone of suburbanization has risen by approximately 37,000. These are mainly newcomers of Lithuanian origin, who are likely to have different political preferences than the original (Polish) population in the region. We hypothesize that our aggregate level findings implicate that on the individual level the inflow of Lithuanians has led to an increased participation of Poles in the elections and increased numbers of votes for the Polish party.

\section{Spatial variation in voting turnout}

The region surrounding Vilnius stands out for its exceptionally high voting turnout in the municipal elections, and for a relatively low turnout in the central government elections since the restoration of Lithuanian independence (Central Electoral Commission 2012). In 2011, in many of the voting districts, voter turnout exceeded $60 \%$, while both in Vilnius city and the rest of Lithuania the average turnout in the municipal elections was only $44 \%$. This is the opposite of what can be observed in the rest of Lithuania, where voting turnout in the elections of central government - Parliamentary as well as Presidential - is highest. These differences suggest that among the residents in the region surrounding the city of Vilnius the regional (Polish) identity is stronger than the national Lithuanian identity (see also Chernyha and Burg 2012). Furthermore, the mass media in Lithuania as well as the EAPL itself often depicts the Polish population as Poles in Lithuania, not Lithuanian Poles (it is even stated in the name of the party).

Voting turnout in the 1997 and 2011 municipal elections in the city of Vilnius and the surrounding region is shown in Figures 7 and 8. It can be seen that voting turnout is the lowest in the city and the highest in the region surrounding it. As mentioned above, there was a general increase in voting turnout in the whole of Lithuania between 1997 and 2011, but it was higher in the Vilnius region. The maps show that the most 'active' areas in 2011 correspond with the areas of the highest proportion of Polish residents (compare Figures 7 and 1). This is also confirmed by the positive correlation between the share of the Polish population and voting turnout (Table 3 ). These aggregate level results suggest that the Polish identity voters in the suburban ring show an increase in voting turnout, and this is what we expected to find. However, more research on the individual level is needed to confirm this.

Although the correlation was stronger in the zone of suburbanization in the elections of 1997, it became of equal strength across the surrounding city region in the elections of 2011. The reduced correlation in the suburban zone might be explained by the changes in ethnic composition. Newcomers of Lithuanian origin may have a weaker regional identity and therefore little motivation to participate in the local elections. Thus, even with the increasing numbers of votes for the EAPL (and increasing voter turnout of the Polish voters), the general voter turnout decreases in the zone of suburbanization.

Figure 7. Voting Turnout Rates in Voting Districts in the 1997 and 2011 Municipality Elections.

Source: Data provided by the Central Electoral Commission of the Republic of Lithuania. 
Figure 8. Changes in Voting Turnout Rates in Voting Districts in the 1997-2011 Municipality Elections.

Source: Data provided by the Central Electoral Commission of the Republic of Lithuania.

Table 3. The Correlations between the Share of the Polish Population and Voter Turnout in 1997 and 2011 in Municipality Elections on the Level of Seniūnija.

Source: Data provided by Statistics Lithuania and the Central Electoral Commission of the Republic of Lithuania.

\section{Conclusions and Discussion}

The process of rapid urban sprawl, which started right after the restoration of Lithuanian independence, became a main driver of changes in the ethnic composition in the surrounding Vilnius region. This was caused by the inflow of ethnic Lithuanians from the city of Vilnius into its surrounding areas, which are dominated by Polish identity residents. Our main hypothesis was that the inflow of ethnic Lithuanians in the region surrounding the city of Vilnius will lead to a mobilization of the Polish vote of the original population, and that this is reflected in their voting behavior.

Our results showed that there are clear spatial patterns in voting behavior in the Vilnius region. The region surrounding the city is dominated by those who vote for the Polish party (EAPL), while the support for this party is much lower in the city. Analysis of the changes in the share of votes for the EAPL between 1997 and 2011 shows a decrease in the share of votes in the surrounding city region, especially in the suburbanization ring around Vilnius. At the same time we observed a stark increase in the absolute number of votes for the EAPL in the zone of suburbanization, and we found an increase in voter turnout in the region, especially in the parts with the higher proportion of Polish population. These aggregate level findings suggest that the Polish population has a stronger local identity than the suburbanizing Lithuanian population, and that Poles are concerned about their representation in municipal government.

For our analyzes we only had access to aggregate level data and not individual level data. The latter is needed to be able to say anything conclusive on the mechanisms at play at the individual level. However, since the results of post-election opinion surveys (Lithuanian HSM data archive, 2004-2010) show that it is mainly Polish identity people who vote for the EAPL, we suggest the following tentative conclusions. The dropping share of votes for the EAPL in the suburbanization ring is most likely the result of the voter migration effect: Lithuanians from the city move to the suburban ring and vote for different parties than the original population in the region. At the same time we see an increase in the absolute number of votes for the EAPL in the suburban ring and increased voter turnout. From this we tentatively conclude that the Polish identity residents of the region show increased voter turnout in an attempt to protect their weakening position in local politics. Although the Polish party still receives more than $50 \%$ of the votes in the majority of the voting districts, the continuing process of suburbanization poses a threat that the EAPL will lose its dominant positions in the future.

We expect that those places which show increased voting turnout, but dropping shares of votes for the EAPL, are places of potential tensions between ethnic groups. Those are the places where the differences in needs, priorities, worldviews, etc., are the greatest between 
two very different ethnic groups. Increasing media attention with regard to these tensions shows that the educational system is now among the main disputes in the region. The tensions mostly occur because the national government wants to transform the network of small Polish-language schools. According to the national policy, small schools need to be closed in order to increase the effectiveness of the educational system. However, in the Vilnius region this policy is opposed by the Polish minority who regard the policy as discrimination. Since municipalities are responsible for the implementation of the national education policy in Lithuania, the situation in the Vilnius region is quite tense.

Notwithstanding the fact that electoral data is not perfect, and does not represent all aspects of political preferences of residents, the data proved to be useful in identifying areas of potential future ethno-political tensions. Using electoral data has also shown to be a useful tool to investigate the spatial patterns of suburbanization as well as the processes of the formation of ethnic and regional identities. The main weakness of the data we used is that it is aggregate level data, and not individual level data. The consequence of this is that we can only speculate on the individual level mechanisms behind what we found on the aggregate level. A detailed survey linking ethnicity, voter behavior, and value orientations could supplement the results of our study and would contribute to a better understanding of the local ethnic and political context. This should be the subject for the future research in order to better assess the ethno-political situation in the Vilnius region.

\section{Acknowledgements}

We would like to thank the Lithuanian Education Exchanges Support Foundation (grant No. LLP-LdV-PLM-2012-LT-0742) for financial support through the Leonardo da Vinci programme initiated by European Union. We would also like to thank the host institution, the OTB - Research for the Built Environment, Faculty of Architecture and the Built Environment, Delft University of Technology in the Netherlands, for its hospitality and for the facilities and office space supplied. We would also like to thank the anonymous reviewers for their insights and comments. Part of the research leading to these results (Prof Dr Maarten van Ham) has received funding from the Marie Curie programme under the European Union's Seventh Framework Programme (FP/2007-2013) / Career Integration Grant n. PCIG10-GA2011-303728 (CIG Grant NBHCHOICE, Neighbourhood choice, neighbourhood sorting, and neighbourhood effects).

\section{References}

15min.lt. (2012) Vilniaus priemiesčio gyventojai: Šalia sostinès gyvenantys lietuviai jaučiasi niekam neįdomi tautine mažuma. [Vilnius suburban residents: Lithuanians living near the capital city feel like they are ignored ethnic minority]. Accessed on 31 May 2013 at http://www.15min.lt/naujiena/aktualu/lietuva/vilniaus-priemiescio-gyventojai-saliasostines-gyvenantys-lietuviai-jauciasi-niekam-neidomi-tautine-mazuma-56-263943

15min.lt. (2013) Polish MEP Pawel Zalewski: Settling name-spelling issue in Lithuania would undermine Polish party's ability to mobilize support. Accessed on 31 May 2013 at http://www.15min.lt/en/article/politics/polish-mep-pawel-zalewski-settling-namespelling-issue-in-lithuania-would-undermine-polish-party-s-ability-to-mobilizesupport-526-329917

Alkas.lt (2012) Vilniuje - lenku nacionalistu mitingas prieš Lietuvos švietimo ìstatyma. [Polish nationalists rally against the Lithuanian law on education]. Accessed on 31 
May 2013 at http://alkas.lt/2012/03/17/vilniuje-lenku-nacionalistu-mitingas-prieslietuvos-svietimo-istatyma/

Andžejevski, T. (2014). Neišspręstos lenku mažumos problemos Lietuvoje kelia grèsme jos egzistencijai. [Unsolved problems of the Polish minority in Lithuania poses a threat to its exsistence]. Accessed on 24 February 2014 at http://www.awpl.lt /index.php?option=com_content\&view =article\&id=67\%3Anierozwizane-problemyspoecznoci-polskiej-na-litwie-zagraaj-jejegzystencji\&catid=42\%3Aaktualia\&Itemid $=59 \&$ lang $=\mathrm{lt}$

Audenienè, R. (2013) Darželiu trūkumas priešina vilniečius ir ne vilniečius tèvus. [Lack of kindergartens opposes parents of Vilnius and its suburbs]. Accessed on 31 May 2013 at http://www.alfa.lt/straipsnis/15132622/Darzeliu.trukumas.priesina.vilniecius.ir.ne. vilniecius.tevus=2013-04-20_09-58/

Bertaud, A. and Renaud, B. 1997. "Cities without Land Markets." Journal of Urban Economics 41 (1): 137-51.

Bonvalet, C., Carpenter, J. and White, P. 1995. "The residential mobility of ethnic minorities: A longitudinal analysis." Urban Studies 32 (1): 87-103.

Boren, T. and Gentile, M. 2007. "Metropolitan processes in post-communist states: An introduction". Geografiska Annaler 89 (2): 95-110.

Brade, I., Herfer, G. and Wiest, K. 2009. "Recent trends and future prospects of socio-spatial differentiation in urban regions of Central and Eastern Europe: A lull before the storm?" Cities 26 (5): 233-44.

Bullock, C.S. and Hood, M.V. 2006. "A Mile-Wide Gap: The Evolution of Hispanic Political Emergence in the Deep South.” Social Science Quarterly 87 (5): 1117-135.

Burneika, D. and Ubarevičienè, R. 2011. "The sprawl of Vilnius city - some consequences of rural - urban transformations.“ Annales Geographicae 43-44: 108-15.

Central Electoral Commission. 2012. 1993-2011 electoral data, accessed on 20 October 2012 at www.vrk.lt.

Chandra, K and Wilkinson, S. 2008. "Measuring the Effect of "Ethnicity". Comparative Political Studies 41 (4-5): 515-63.

Chernyha, L.T. and Burg, S.L. 2012. "Accounting for the Effects of Identity on Political Behavior: Descent, Strength of Attachment, and Preferences in the Regions of Spain." Comparative Political Studies 45 (6): 774-803.

Cirtautas, M. 2013. "Urban sprawl of major cities in the Baltic States". Architecture and Urban Planning 7: 72-79.

Clark, W. 2006. "Race, class, and space: Outcomes of suburban access for Asians and Hispanics." Urban geography 27 (6): 489-506.

Commercio, M. E. 2004. "Exit in the near abroad: the Russian minorities in Latvia and Kyrgyzstan." The Problems of Post-Communism 51 (6): 23-32.

Crowley, J. 2001. "The Political Participation of Ethnic Minorities." International Political Science Review 22 (1): 99-121.

Daukšas, D. 2008. "Pase įrašytoji tapatybè: Lietuvos lenkų etninio/nacionalinio tapatumo trajektorijos." [Identity Inscribed in the Passport: the Trajectories of Ethnic/national Identity of Lithuanian Poles]. Lietuvos etnologija 17: 57-72.

Degutis, M. 2002. "Rinkiminio elgesio dinamika Lietuvoje 1992-2001 m." [Dynamics of electoral behaviour in Lithuania in 1992-2001]. (doctoral dissertation). Vilnius.

Delfi.lt. (2014). B. Juodka: lenku tautinès mažumos problemos yra dirbtinai eskaluojamos. [B. Juodka: the problems of the Polish ethnic minority are exaggerated]. Accessed on 24 February 2014 at http://www.delfi.lt/news/daily/lithuania/b-juodka-lenku-tautinesmazumos-problemos-yra-dirbtinai-eskaluojamos.d?id=63956604\#ixzz2uEgNlbiP 
Eberhardt, P. 2006. "Polish Eastern border changes in 1939-1945". Annales Geographicae 39(2): 29-44.

Enyedi, G. 1996. "Urbanization under socialism." In Cities after Socialism: Urban and Regional Change and Conflict in Post-socialist Societies, edited by Andrusz G., Harloe, M. and Szelenyi, I., 100-18. Oxford: Blackwell Publishers.

Fennema M. and Tillie J. 2001. "Civic Community, Political Participation and Political Trust of Ethnic Groups." Connections 24 (1): 26-41.

Gaučas, P. 1997 “Etnolingvistiné Rytu Lietuvos gyventoju raida XVII a. antrojoje pusejje 1939 m.: istorine geografine analize." [Ethnolinguistic evolution of the development of population in Eastern Lithuania in the second part of the 17th century - 1939: historical geographical analysis]. (doctoral dissertation). Vilnius.

George, J., Moser, R. G., Papic, M. 2010. "The Impact of Minority-Majority Districts: Evidence from Ukraine." Post-Soviet Affairs 26 (1): 58-76.

Halla, M., Wagner, A. F. and Zweimüller, J. 2012. "Does Immigration into Their Neighborhoods Incline Voters Toward the Extreme Right? The Case of the Freedom Party of Austria." www.iza.org

Hamilton, F.E.I., Andrews, K.D. and Pichler-Milanovic, N. 2005. Transformation of Cities in Central and Eastern Europe - Towards Globalization. Tokyo: United Nations University Press.

Harrison, J. 2010. "Networks of connectivity, territorial fragmentation, uneven development: The new politics of city-regionalism.“ Political Geography 29 (1): 17-27.

Hiebert, D. 2000. "Immigration and the changing Canadian city." The Canadian Geographer 44 (1): 25-43.

Kok, H. and Kovács, Z. 1999. "The Process of Suburbanization in the Agglomeration of Budapest." Netherlands Journal of Housing and Built Environment 14 (2): 119-41.

Krišjāne, Z. and Bērziņš, M. 2009. "Commuting and the Deconcentration of the Post-Socialist Urban Population: The Case of the Rìga Agglomeration." Folia Geographica 14: 5674.

Lawson K. 1999. "Cleavages, parties and voters.” In Cleavages, Parties, and Voters-Studies from Bulgaria, the Czech Republic, Hungary, Poland, and Romania (Political Parties in Context), edited by Lawson K., Römmele A. and Karasimeonov G., 19-36. Praeger Publishers: Westport.

Leetmaa, K. and Tammaru, T. 2007. "Suburbanization in Countries in Transition: Destinations of suburbanisers in the Tallinn metropolitan area." Geografiska Annaler, Series B Human Geography 89 (2): 127-46.

Lipset S. M. and Rokkan S. 1967. "Cleavage structures, party systems, and voter alignment: An introduction." In Party Systems and Voter Alignments, edited by Lipset, S.M. and Rokkan, S. Free Press: New York.

Lithuanian HSM data archive. 2004-2010 pre- and post-electoral surveys data. http://www.lidata.eu/en/index.php

Media. (2013) Poles in Lithuania expect steps to resolve their problem to be put into execution. Accessed on 1 June 2013 at http://media.efhr.eu/2013/02/06/poleslithuania-expect-steps-resolve-problem-put-execution/

Medrano, J. D. 1994. "The Effects of Ethnic Segregation and Ethnic Competition on Political Mobilization in the Basque Country, 1988." American Sociological Review 59 (6): 873-89.

Miškinytè, Ž. (2011) Lenku rinkimu akcijos mitingas: rinkiminiai šūkiai ir tikrove. [The rally of Polish Electoral Action: an electoral slogans and reality]. Accessed on 1 June 2013 
at http://alkas.lt/2011/09/27/z-miskinyte-lenku-rinkimu-akcijos-mitingas-rinkiminiaisukiai-ir-tikrove/

Novak, J. and Sýkora, L. 2007. "A City in Motion: Time-Space Activity and Mobility Patterns of Suburban Inhabitants and the Structuration of the Spatial Organization of the Prague Metropolitan Area." Geografiska Annaler Series B Human Geography 89 (2): 147-67.

Nuissl, H. and Rink, D. 2005. "The 'product' of urban sprawl in eastern Germany as a phenomenon of post-socialist transformation." Cities 22 (2): 123-34.

Ouředníček, M. 2007. "Differential Suburban Development in the Prague urban Region." Geografiska Annaler Series B Human Geography 89 (2): 111-26.

Petrulis, V. 2009. "Lietuvos politinio lauko teritoriné struktūra (elektorinio metodo pagrindu)." [A territorial structure of Lithuania's political field (On the basis of electoral method]. (doctoral dissertation). Vilnius.

Press Europe. (2009) You say Waldemar, I say Valdemar. Accessed on 1 June 2013 at http://www.presseurop.eu/en/content/news-brief/133621-you-say-waldemar-i-sayvaldemar

Ramonaite, A., Maliukevičius, N., Degutis, M. 2007. "Tarp Rytu ir Vakarų: Lietuvos visuomenés geokultūrinés nuostatos. " [Between East and West: Geo-cultural attitudes of Lithuanian society]. Vilnius: Versus Aureus.

Respublika. (2011 04 06) V. Tomaševskis: lietuviai turi integruotis, o ne mes. [V. Tomaszewski: Lithuanians have to integrate, not we]. Accessed on 1 June 2013 at http://www.respublika.lt/lt/naujienos/lietuva/lietuvos_politika/vtomasevskis_lietuviai_ turi_integruotis_o_ne_mes/

Robinson, T. and Noriega, S. 2010. "Voter migration as a source of electoral change in the Rocky Mountain West." Political Geography 29 (1): 28-39.

Šešelgis, K. 1996. "Teritorijų planavimo raida Lietuvoje [Development of regional planning in Lithuania], Urbanistika ir architektura, 1 (21): 4-19.

Simpson, L. and Finney, N. 2009. "Spatial Patterns of Internal Migration: Evidence for Ethnic Groups in Britain." Population, Space And Place 15 (1): 37-56.

Stanaitis, A. 2003. "Tautiniai pokyčiai Vilniaus mieste XX a. II puseje." [Changes in the national structure of the Vilnius city in the second half of the 20th century]. Geografija 39 (1): 33-39.

Stanaitis, S. and Česnavičius, D. 2010. "Dynamics of national composition of Vilnius population in the 2 nd half of the 20th century." Bulletin of Geography. Socioeconomic series 13: 31-44.

Statistics Lithuania. 2002. 2001 Census data special request tables.

Statistics Lithuania. 2011. www.statgov.lt, accessed on 12 October 2012.

Statistics Lithuania. 2012 Lithuanian 2011 Population Census in Brief, Vilnius: Statistics Lithuania.

Statistics Lithuania. 2013. 2011 Census data special request tables.

Stravinskienè, V. 2004. "Lenkai Lietuvoje. $1944 \mathrm{~m}$. antroji pusė - 1946 metai: tarp pasirinkimo likti ar išvykti i Lenkiją?" [Poles in Lithuania from the second half of 1944 until 1946: choosing between staying or emigrating to Poland]. Lietuvos istorijos metraštis 2: 94-115.

Sýkora, L. and Ćermák, Z. 1998. "City growth and migration patterns in the context of 'communist' and 'transitory' periods in Prague's urban development." Espace, populations and societies 3: 405-16.

Sýkora, L. and Ouředníček, M. 2007. "Sprawling post-communist metropolis: Commercial and residential suburbanization in Prague and Brno, the Czech Republic." In 
Employment Deconcentration in European Metropolitan Areas, edited by Razin, E. et al., 209-33. Netherlands: Springer.

Tammaru, T. and Kulu, H. 2003. "The Ethnic Minorities of Estonia: Changing Size, Location, and Composition." Eurasian Geography and Economics 44 (2): 105-20.

Tammaru, T., Leetmaa, K., Silm, S. and Ahas, R. 2009. "Temporal and Spatial Dynamics of the New Residential Areas around Tallinn." European Planning Studies 17 (3): 42339.

Tammaru, T., van Ham, M., Leetmaa, K., Kahrik, A. and Kamenik, K. 2013. "The Ethnic Dimension of Suburbanization in Estonia." Journal of Ethnic and Migration Studies, 39(5): 845-62

The Economist. (2012) Dialogue of the deaf between Vilnius and Warsaw. Accessed on 1 June 2013 at http://www.economist.com/blogs/easternapproaches/2012/02/polandand-lithuania

The Lithuania Tribune. (2013) Rally against the language demands made by Lithuanian Poles' Electoral Action. Accessed on 31 May 2013 http://www.lithuaniatribune.com./34892/rally-against-the-language-demands-madeby-lithuanian-poles-electoral-action-201334892/

Timar, J. and Varadi, M. M. 2001. "The Uneven Development of Suburbanization during Transition in Hungary." European Urban and Regional Studies 8 (4): 349-60.

Togeby, L. 1999. "Migrants at the polls: An analysis of immigrant and refugee participation in Danish local elections.” Journal of Ethnic and Migration Studies 25 (4): 665-84.

Ubarevičienè, R., Burneika, D. and Kriaučiūnas, E. 2011. "The sprawl of Vilnius city establishment and analysis of growing urban region." Annales Geographicae 43-44: 96-107.

van Heelsum, A. 2005. "Political Participation and Civic Community of Ethnic Minorities in Four Cities in the Netherlands." Politics 25 (1): 19-30.

Vanagas, J., Krišjane, Z., Noorkoiv, R. and Staniūnas, A. 2002. "Planning urban systems in Soviet times and in the era of transition: The case of Estonia, Latvia and Lithuania." Geographia Polonica 75 (2): 75-100.

Walks, A. 2004. "Place of residence. Party preferences, and political attitudes in Canadian cities and suburbs." Journal of Urban Affairs 26 (3): 269-95.

Walks, A. 2005. "City-suburban electoral polarization in Great Britain, 1950-2001." Transactions of the Institute of British Geographers 30(4): 500-17.

Walks, A. 2006. "The Causes of City-Suburban Political Polarization? A Canadian Case Study". Annals of the Association of American Geographers 96 (2): 390-414.

Wolfinger, E. 1965. "The Development and Persistence of Ethnic Voting." The American Political Science Review 59 (4): 896-908. 


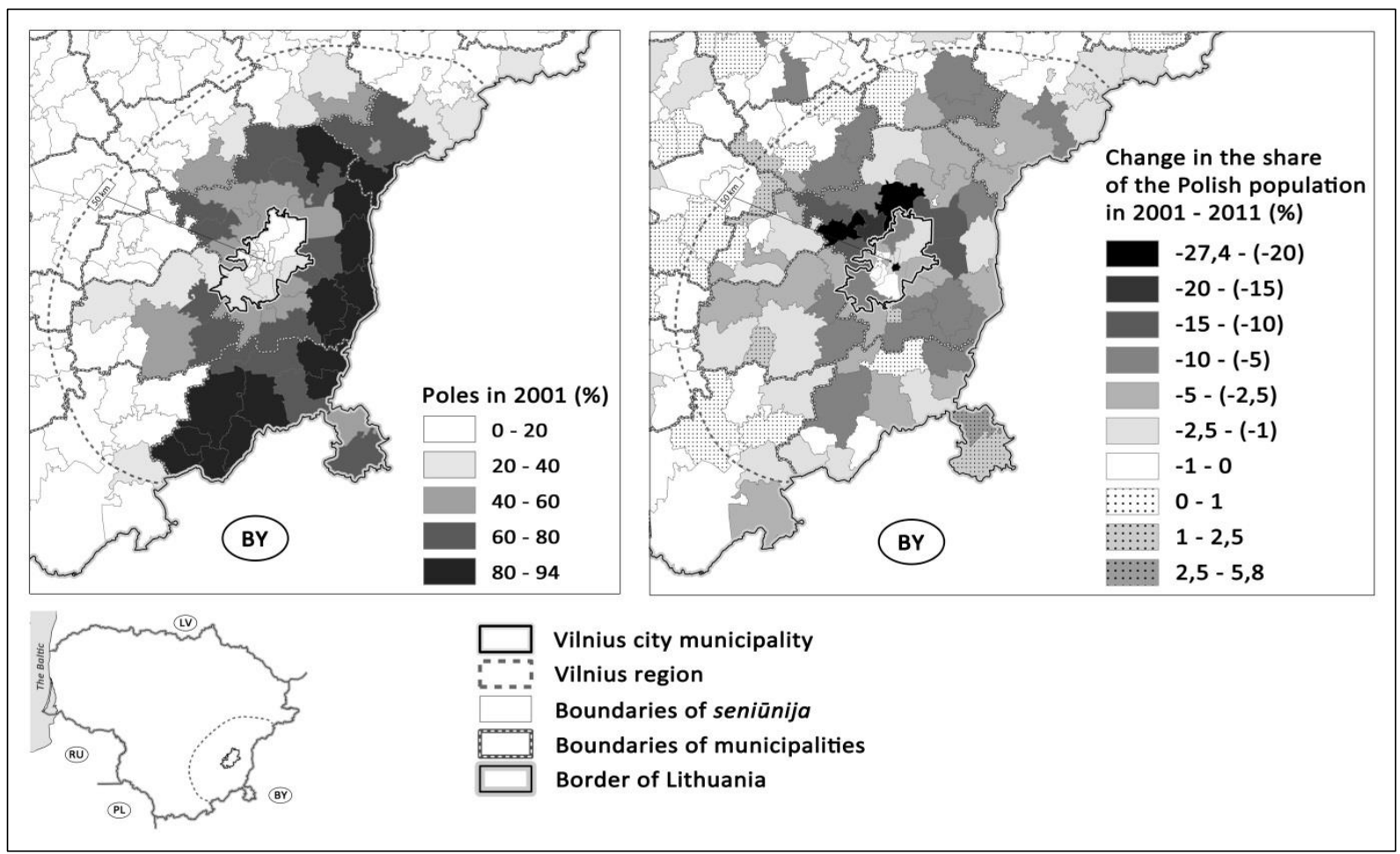

Figure 1. Ethnic Landscape of the Vilnius region.

Source: Data provided by Statistics Lithuania.

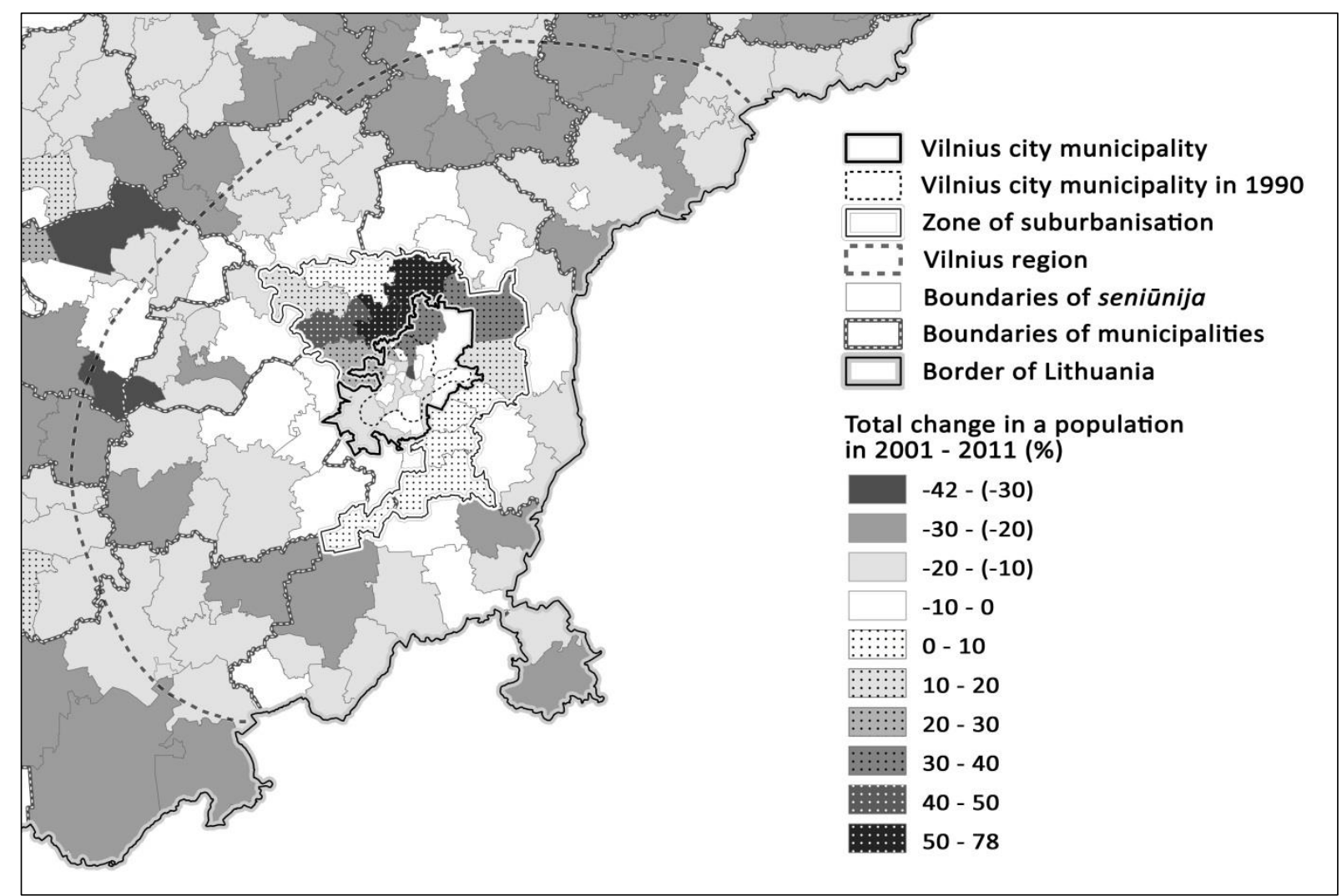

Figure 2. Urban Sprawl of Vilnius.

Source: Data provided by Statistics Lithuania. 


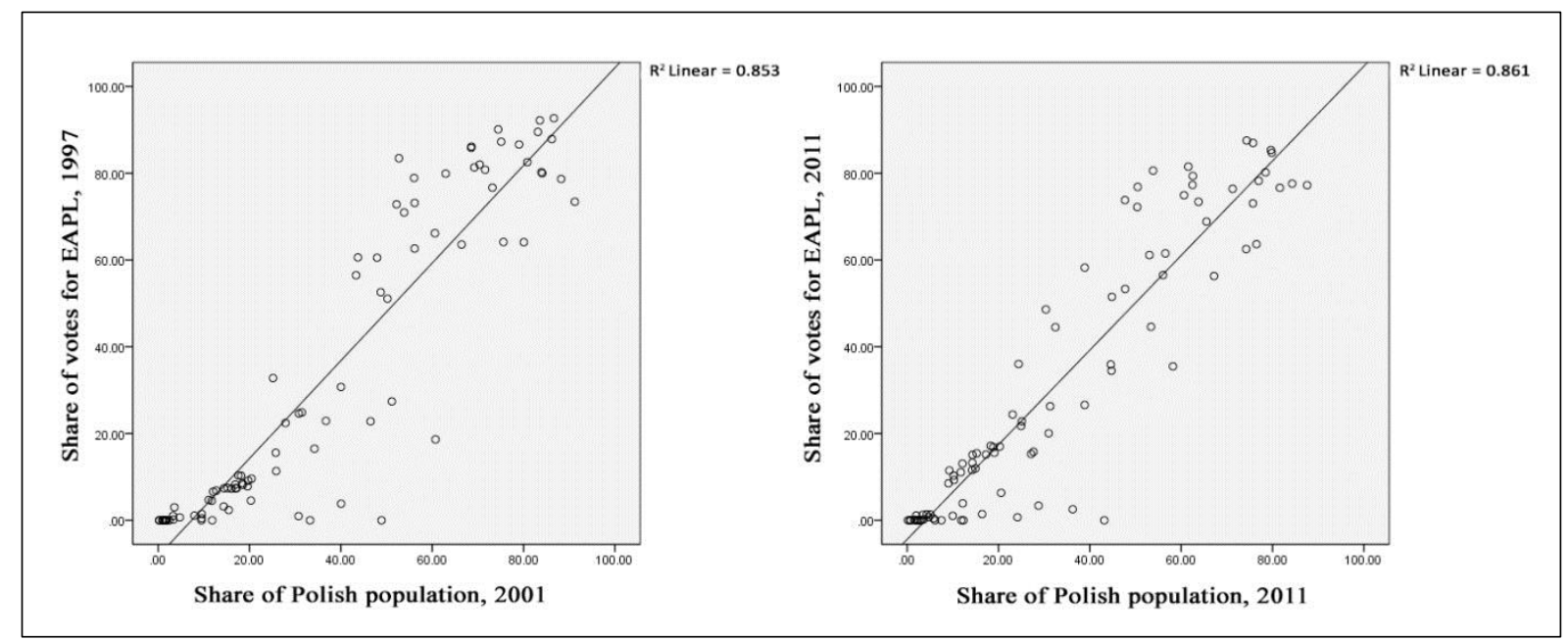

Figure 3. Share of the Polish Population and Share of Votes for the EAPL on the Level of Seniūnija.

Source: Data provided by Statistics Lithuania and the Central Electoral Commission of the Republic of Lithuania.

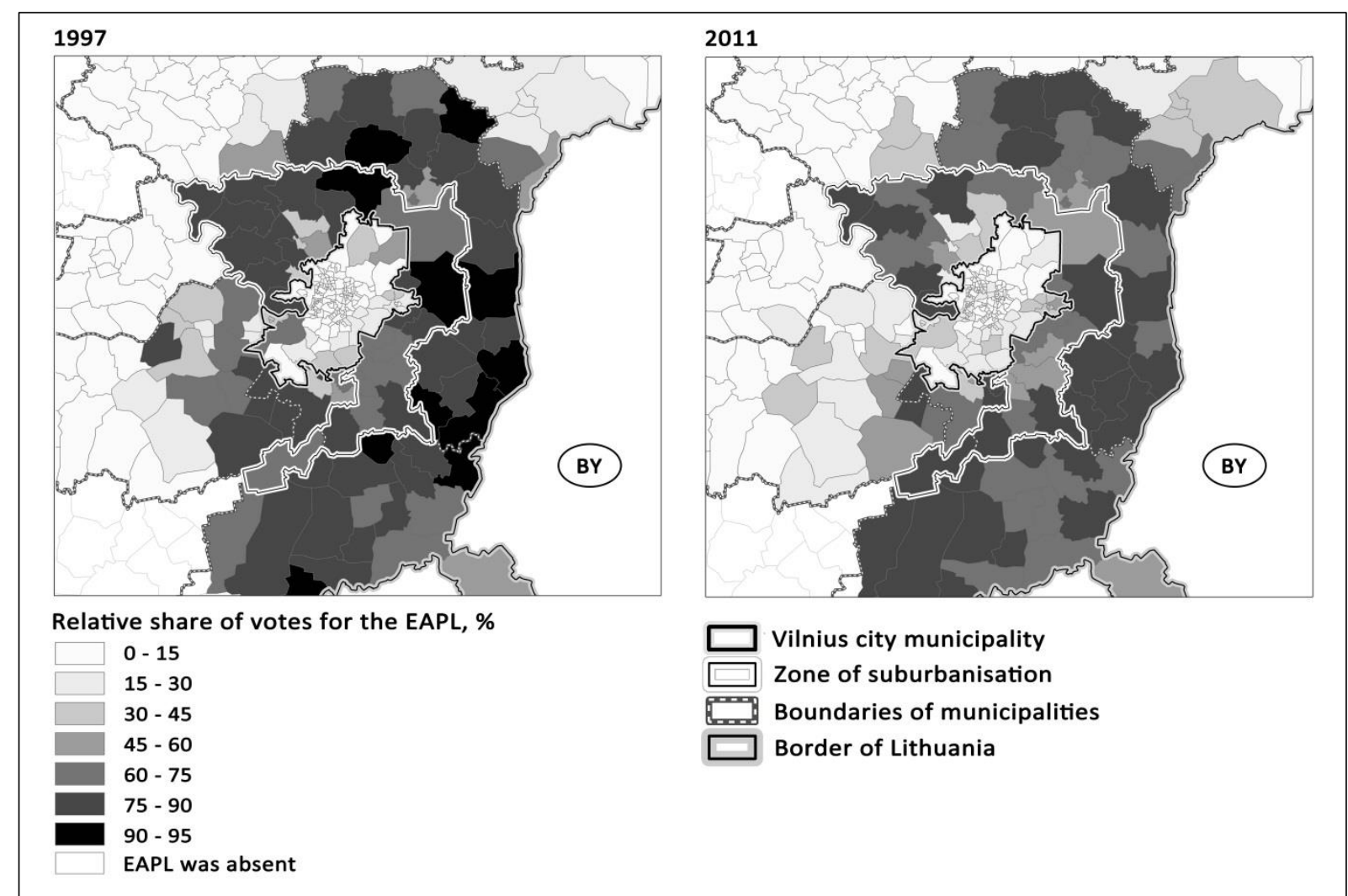

Figure 4. Relative Share of Votes for the EAPL in Voting Districts in the 1997 and 2011 Municipality Elections.

Source: Data provided by the Central Electoral Commission of the Republic of Lithuania. 


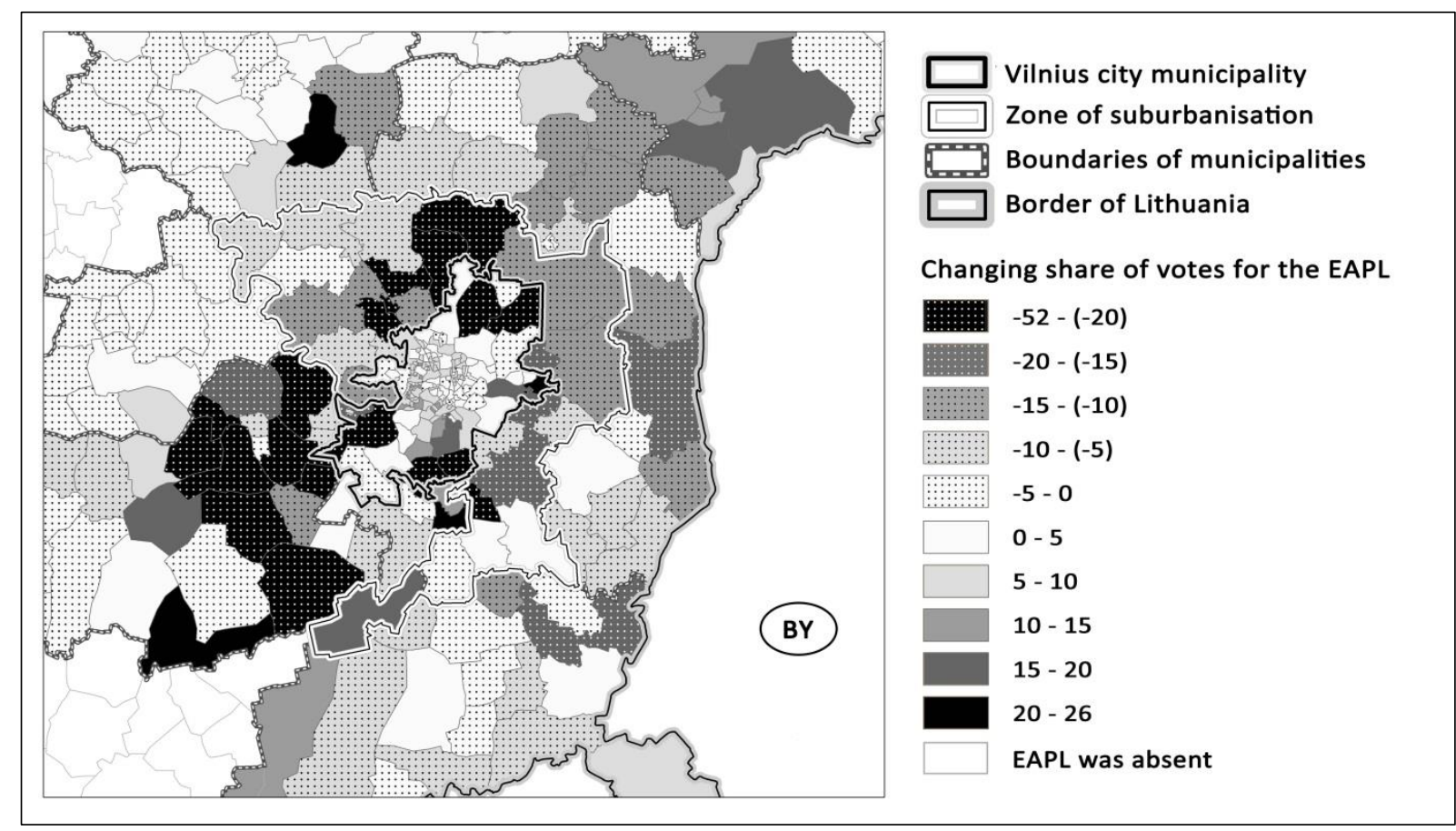

Figure 5. Changing Share of Votes for the EAPL in Voting Districts in the 1997-2011 Municipality Elections.

Source: Data provided by the Central Electoral Commission of the Republic of Lithuania.

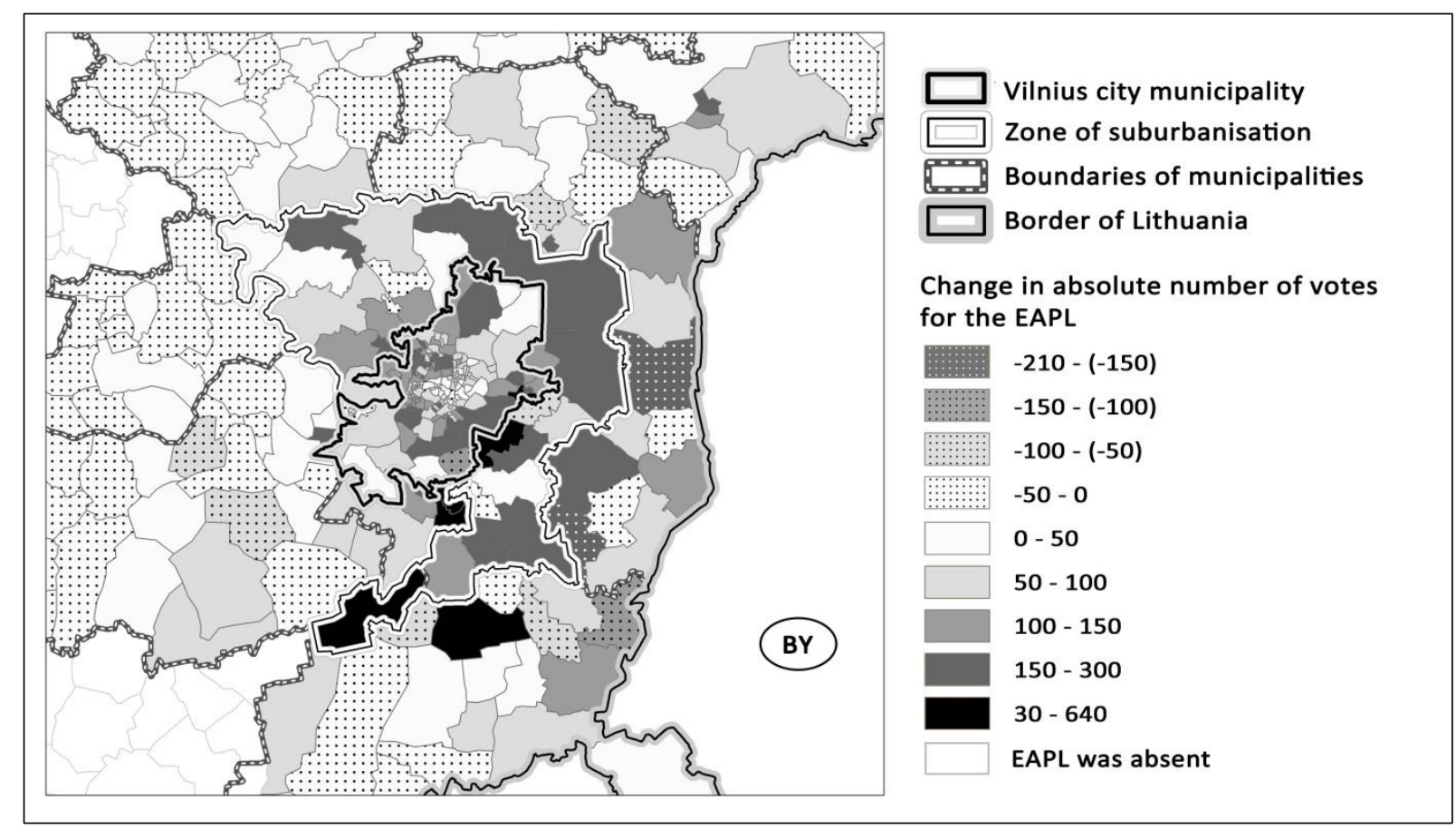

Figure 6. Change in the Absolute Number of Votes for the EAPL in Voting Districts in the 1997-2011 Municipality Elections.

Source: Data provided by the Central Electoral Commission of the Republic of Lithuania. 
Table 1. The Correlations between the Absolute Number of Poles and Absolute Number of Votes for the Polish Party in the 1997 and 2011 Municipal Elections on the Level of Seniūnija.

\begin{tabular}{lll}
\hline & $\mathbf{1 9 9 7}$ & $\mathbf{2 0 1 1}$ \\
\hline Whole region surrounding Vilnius & $\mathrm{r}=.896$ & $\mathrm{r}=.930$ \\
& $\mathrm{n}=68$ & $\mathrm{n}=68$ \\
& $\mathrm{p}<.0005$ & $\mathrm{p}<.0005$ \\
\hline Zone of suburbanisation & $\mathrm{r}=.432$ & $\mathrm{r}=.913$ \\
& $\mathrm{n}=17$ & $\mathrm{n}=17$ \\
& $\mathrm{p}=.083$ & $\mathrm{p}<.0005$ \\
\hline Vilnius region beyond suburban zone & $\mathrm{r}=.903$ & $\mathrm{r}=.935$ \\
& $\mathrm{n}=55$ & $\mathrm{n}=55$ \\
& $\mathrm{p}<.0005$ & $\mathrm{p}<.0005$ \\
\hline
\end{tabular}

Source: Data provided by Statistics Lithuania and the Central Electoral Commission of the Republic of Lithuania.

Table 2. The Ratios of Voting Turnout amongst Different Population Groups in the 1997 and 2011 Municipality Elections on the Level of Seniūnija.

\begin{tabular}{|c|c|c|c|c|c|c|}
\hline & \multicolumn{3}{|l|}{1997} & \multicolumn{3}{|l|}{2011} \\
\hline & 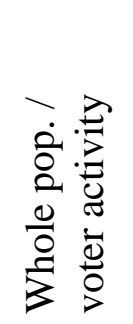 & 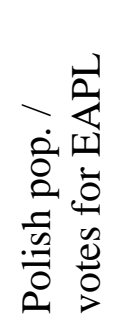 & 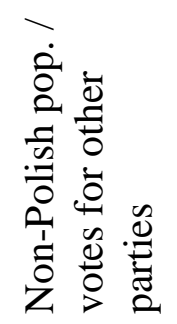 & 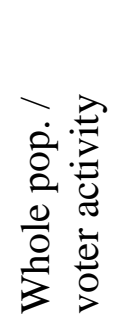 & 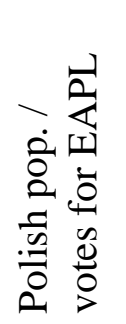 & 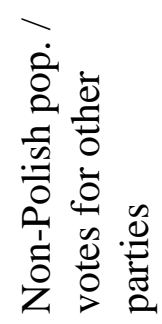 \\
\hline Lithuania & $29.1 \%$ & $22.2 \%$ & $29.6 \%$ & $38.1 \%$ & $37.2 \%$ & $38.1 \%$ \\
\hline $\begin{array}{l}\text { Whole region } \\
\text { surrounding Vilnius } \\
\text { city }\end{array}$ & $31.2 \%$ & $33.2 \%$ & $29.7 \%$ & $44.9 \%$ & $46.7 \%$ & $43.8 \%$ \\
\hline $\begin{array}{l}\text { Zone of } \\
\text { suburbanisation }\end{array}$ & $27.4 \%$ & $28.9 \%$ & $26.7 \%$ & $39.2 \%$ & $46.8 \%$ & $36.9 \%$ \\
\hline $\begin{array}{l}\text { Vilnius region beyond } \\
\text { suburban zone }\end{array}$ & $31.6 \%$ & $30.7 \%$ & $32.1 \%$ & $46.5 \%$ & $43.4 \%$ & $48.5 \%$ \\
\hline
\end{tabular}

Source: Data provided by Statistics Lithuania and the Central Electoral Commission of the Republic of Lithuania. 


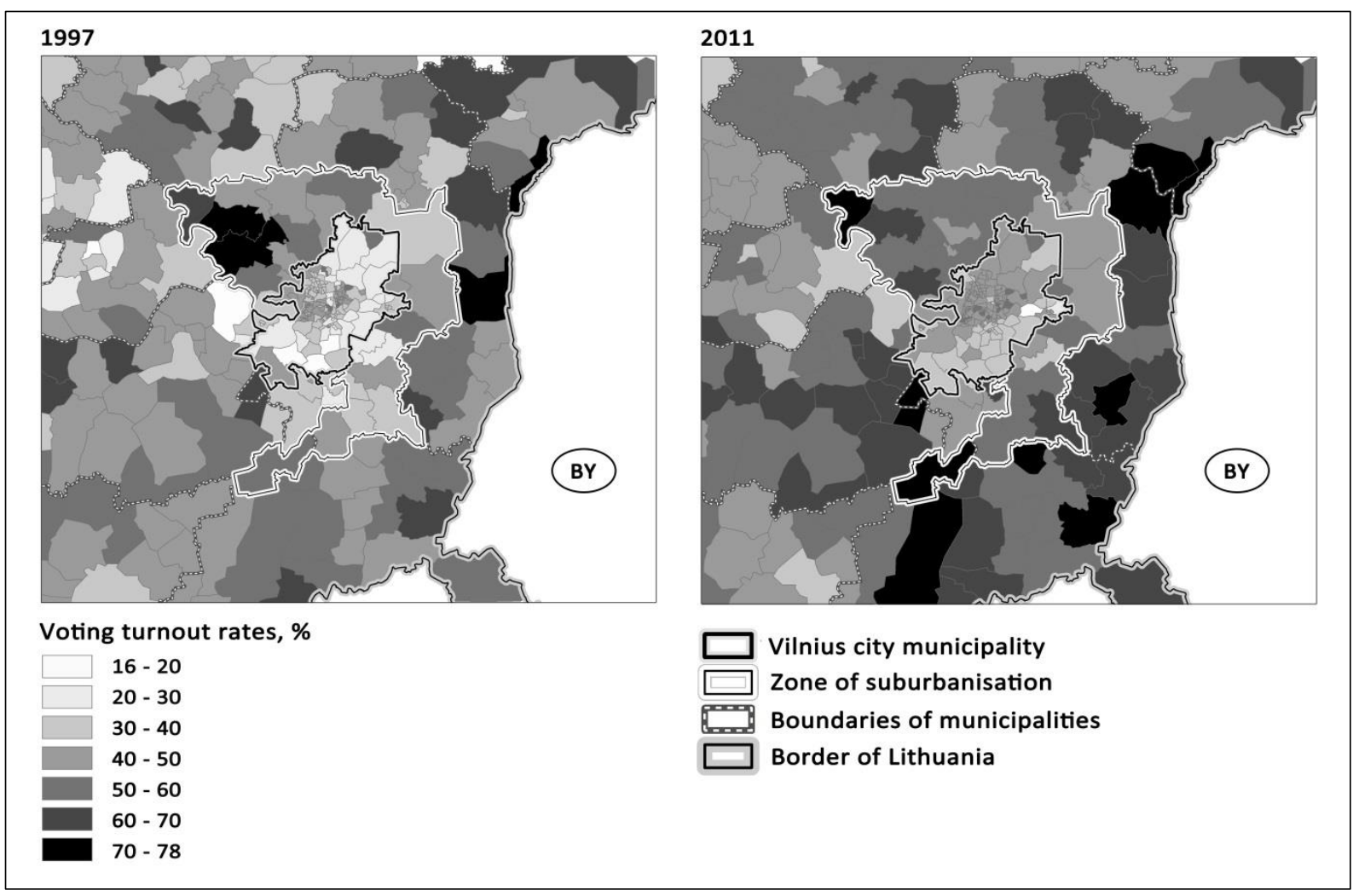

Figure 7. Voting Turnout Rates in Voting Districts in the 1997 and 2011 Municipality Elections.

Source: Data provided by the Central Electoral Commission of the Republic of Lithuania.

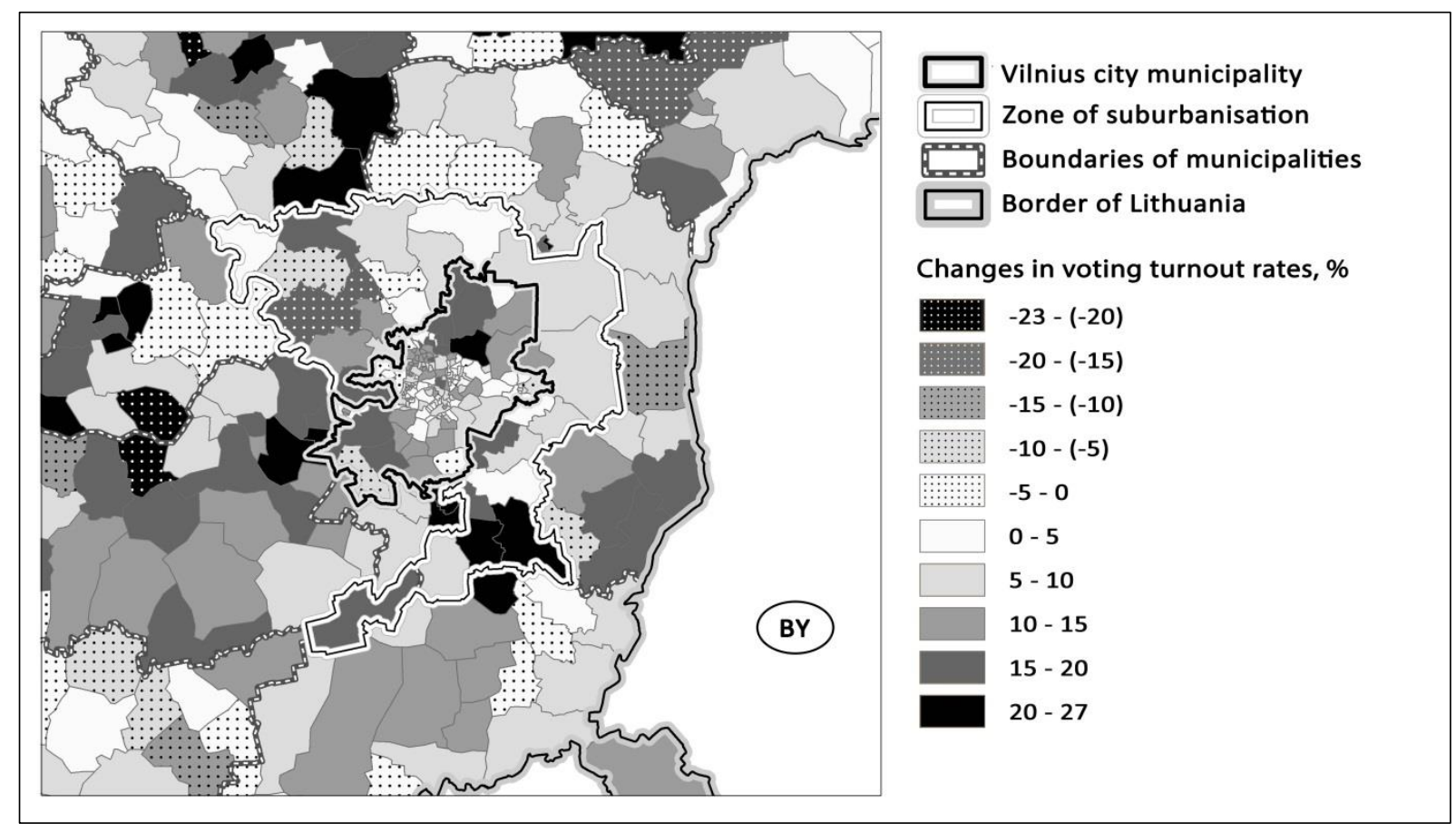

Figure 8. Changes in Voting Turnout Rates in Voting Districts in the 1997-2011 Municipality Elections.

Source: Data provided by the Central Electoral Commission of the Republic of Lithuania. 
Table 3. The Correlations between the Share of the Polish Population and Voter Turnout in 1997 and 2011 in Municipality Elections on the Level of seniūnija.

\begin{tabular}{lll}
\hline & $\mathbf{1 9 9 7}$ & $\mathbf{2 0 1 1}$ \\
\hline Whole region surrounding Vilnius & $\mathrm{r}=.438$ & $\mathrm{r}=.535$ \\
& $\mathrm{n}=68$ & $\mathrm{n}=68$ \\
& $\mathrm{p}<.0005$ & $\mathrm{p}<.0005$ \\
\hline Zone of suburbanisation & $\mathrm{r}=.609$ & $\mathrm{r}=.575$ \\
& $\mathrm{n}=17$ & $\mathrm{n}=17$ \\
& $\mathrm{p}=.009$ & $\mathrm{p}=.016$ \\
\hline Vilnius region beyond suburban zone & $\mathrm{r}=.459$ & $\mathrm{r}=.576$ \\
& $\mathrm{n}=55$ & $\mathrm{n}=55$ \\
& $\mathrm{p}<.0005$ & $\mathrm{p}<.0005$ \\
\hline
\end{tabular}

Source: Data provided by Statistics Lithuania and the Central Electoral Commission of the Republic of Lithuania. 